Volume 4 Nomor 2, Juli-Desember 2020: hlm. 129-142.

Fakultas Hukum, Universitas Lampung,

Bandar Lampung, Lampung, Indonesia.

E-ISSN: 2598-3105 P-ISSN: 2723-2581

http://jurnal.fh.unila.ac.id/index.php/cepalo

\title{
PERTANGGUNGJAWABAN PEMERINTAH REPUBLIK INDONESIA TERHADAP HILANGNYA HAK ATAS TANAH MILIK WARGA \\ MASYARAKAT YANG TERKENA ABRASI DI WILAYAH KABUPATEN BREBES JAWA TENGAH
}

\section{THE REPUBLIC OF INDONESIA GOVERNMENT RESPONSIBILITY OF THE CITIZEN LOSS LAND AFFECTED NY ABRATION IN THE REGION OF THE BREBES REGENCY OF CENTRAL JAVA}

\section{Christopher Kendrick Adam ${ }^{1}$, Joe Arifiando Walpa ${ }^{2}$, Vina Octavia ${ }^{3}$}

${ }^{1}$ Fakultas Hukum Universitas Tarumanagara, Email: kendrickadamc@ gmail.com

${ }^{2}$ Fakultas Hukum Universitas Tarumanagara, Email: joearifiando92@gmail.com

${ }^{3}$ Fakultas Hukum Universitas Tarumanagara, Email: vinaoctavia77@gmail.com

Submitted: July 14, 2020; Reviewed: July 30, 2020; Accepted: August 10, 2020

DOI: 10.25041/cepalo.v4no2.1943

\begin{abstract}
Abstrak
Abrasi yang terjadi pada Kabupaten Brebes pada bulan Februari 2020, berdasarkan data dari Badan Penanggulangan Bencana Daerah (BPBD) Kabupaten Brebes, menimbulkan dampak yang luar biasa. Sekian banyak tanah yang hilang disebabkan oleh abrasi pantai yang menyebabkan hilangnya luas tanah yang dimiliki oleh masyarakat. Masyarakat Kabupaten Brebes yang memiliki hak atas tanah yang hilang tersebut membutuhkan perlindungan hukum atas tanah nya yang musnah. Status hukum atas tanah yang musnah karena terkena abrasi pun musnah. Negara tidak dapat memberikan perlindungan hukum terhadap tanah yang musnah. Dalam Pasal 27 UUPA huruf $b$ tentang hapusnya hak atas tanah, tanah yang musnah berarti tanahnya hapus. Oleh sebab itu, hilangnya tanah karena faktor alam, seperti abrasi tidak dapat dimintai pertanggungjawaban terhadap negara, terkecuali jika pemerintah terbukti tidak melakukan upaya-upaya pencegahan yang semestinya. Upaya yang dilakukan oleh pemerintah dapat dilihat sebagai bentuk tanggung jawab public pemerintah. Pemerintah dalam hal ini semestinya dapat melakukan upaya pencegahan dalam menjaga kondisi alam sekaligus hak-hak masyarakat terhadap tanah yang dimiliki rakyat. Namun, apabila masyarakat merasa tindakan pencegahan tersebut kurang tepat dalam mencegah bencana abrasi maka masyarakat setempat dapat mengajukan gugatan Class Action melalui Pengadilan Negeri setempat.
\end{abstract}

Kata Kunci: Abrasi, Pemerintah, Pertanggungjawaban, Tanah.

\section{Abstract}

The abrasion that occurred in Brebes Regency in February 2020, based on data from the Regional Disaster Management Agency (BPBD) of Brebes Regency, had an extraordinary 
impact. So much land has been lost due to coastal abrasion which has resulted in the loss of land area owned by the community. The people of Brebes Regency who have rights to the lost land need legal protection for their destroyed land. The legal status of land that was destroyed due to abrasion has also been destroyed. The state cannot provide legal protection for destroyed land. In Article 27 of the UUPA letter b concerning the abolition of land rights, destroyed land means that the land is abolished. Therefore, the loss of land due to natural factors, such as abrasion, cannot be held accountable to the state, unless the government is proven not to have taken proper preventive measures. The efforts made by the government can be seen as a form of government public responsibility. The government in this case should be able to take preventive measures in protecting natural conditions as well as the community's rights to land owned by the people. However, if the community feels that these precautions are not appropriate in preventing abrasion, the local community can file a Class Action lawsuit through the local District Court.

Keywords: Abrasion, Land, Government, Accountability.

\section{A. Pendahuluan}

Wilayah pesisi adalah wilayah yang sangat berpotensi memiliki degradasi terhadap lingkungan. Fenomena seperti pencemaran lingkungan, adanya habitat yang telah rusak dan adanya pengambilan sumberdaya alam yang berlebihan dan salah satunya adalah abrasi pantai, serta adanya perubahan kawasan lindung menjadi tempat pembangunan serta berbagai bencana alam lainnya. ${ }^{1}$ Abrasi adalah pengikisan batuan atau daratan oleh angin, air es, dan gelombang yang dapat berpotensi merusak wilayah atau bangunan disekitarnya. ${ }^{2}$ Menurut Triatmodjo dalam Fadhilah Maharani , mendefinisikan fenomena abrasi adalah salah satu masalah yang menjadi ancaman bagi kondisi pesisir, yang dapat memberikan dampak negative bagi garis pantai sehingga mundur kebelakang, efek seperti adanya kerusakan tambak dan merusak adanya wilayah persawahan yang posisinya ada di pinggir pantai, dan juga memberikan dampak negative bagi bangunan yang bersinggungan langsung dengan air laut, baik bangunan yang digunakan sebagai penunjang wisata maupun rumah penduduk. Abrasi pantai diartikan dan memiliki makna suatu kondisi yang menyebabkan mundurnya garis pantai dari posisi awal dan agak lebih menjorok kedalam. Abrasi atau erosi pantai bisa disebabkan melalui pengikisan sedimen yang menyusur pantai sehingga mengakibatkan berpindahnya sedimen dari satu tempat ke tempat lainnya. Angkutan sedimen yang terjadi sepanjang pantai terjadi bila arah gelombang laut ada dan datang membentuk sudut dengan garis yang seharusnya ada di pantai. ${ }^{3}$ Berdasarkan definisi tersebut memperlihatkan bahwa fenomena abrasi sangat berbahaya bagi kelangsungan daratan di daerah pantai, terkhusus daerah pesisi pantai.

Proses abrasi dapat terjadi di banyak tempat, salah satunya di pinggir pantai. ${ }^{4}$ Pinggir pantai merupakan tempat di mana setiap harinya gelombang air laut menghantam daratan beserta batuan dan pasir yang terdapat di atasnya. Abrasi tentu saja menimbulkan dampak negatif bagi kehidupan masyarakat di pinggir pantai. ${ }^{5}$ Muhammad Arsyad (2012) menyatakan: "abrasi

\footnotetext{
1 Fadhilah Maharani Fajrin et al., "KARAKTERISTIK ABRASI DAN PENGARUHNYA TERHADAP MASYARAKAT DI PESISIR SEMARANG BARAT," Diponegoro Journal Of Maquares 5, no. 2 (2016): 4350, 44, DOI: 10.14710/marj.v5i2.11645.

${ }^{2}$ Ibid., 45.

${ }^{3}$ Ibid.

4 Teuku Raihansyah, Ichsan Setiawan, and Thaib Rizwan, "STUDI PERUBAHAN GARIS PANTAI DI WILAYAH PESISIR PERAIRAN UJUNG BLANG KECAMATAN BANDA SAKTI LHOKSEUMAWE," Jurnal Ilmiah Mahasiswa Kelautan Perikanan Unsyiah 1, no. 1 (2016): 46-54, 47.

5 Bambang Sudarsono, "INVENTARISASI PERUBAHAN WILAYAH PANTAI DENGAN METODE PENGINDERAAN JAUH (STUDI KASUS KOTA SEMARANG),” Teknik 32, no. 2 (2012): 162-169, 168,
} 
tentu sangat berdampak terhadap kehidupan. Pada umumnya abrasi lebih banyak memiliki dampak negatif dibandingkan dampak positif. Dampak negatif yang dihasilkan dari abrasi juga sangat merugikan lingkungan khususnya manusia."6 Kerugian yang dialami warga masyarakat yang terkena abrasi terjadi meliputi banyak hal. Kegiatan perekonomian tentu saja dapat terganggu akibat terjadinya abrasi. Selain itu secara hukum masyarakat juga bisa dirugikan jika warga memiliki hak milik atau hak guna atas bagian tanah yang terkena dampak abrasi. ${ }^{7}$ Dampak-dampak negatif dari abrasi membuat hukum harus menyesuaikan dengan perkembangan zaman. Berdasarkan penjelasan tersebut dapat dilihat bahwa abrasi merupakan suatu fenomena alam yang sering terjadi di daerah pesisir pantai dan dikarenakan oleh angin, es dan gelombang laut. Salah satu dampak yang dirasakan oleh masyarakat akibat abrasi ialah berkaitan dengan tanah yang terkikis terus menerus dan menimbulkan tanah milik rakyat berkurang secara signifikan.

Data dari Badan Penanggulangan Bencana Daerah (BPBD) Kabupaten Brebes, awal tahun 2020 abrasi terjadi dengan dampak luar biasa di Kabupaten Brebes. Di Kecamatan Brebes, abrasi mencapai kurang lebih 2.115 Ha dengan rincian: 506,81 Ha di Kabupaten Brebes, 626,15 Ha di Kecamatan Wanasari, 1,98 Ha di Kecamatan Bulakamba, 46,12 Ha di Kecamatan Tanjung, dan 934,33 Ha di Kecamatan Losari. Abrasi di Kabupaten Brebes menyebabkan banyak luas tanah yang hilang, di dalamnya terdapat juga tanah milik warga masyarakat. Masyarakat yang memiliki hak atas tanah yang terkena abrasi membutuhkan perlindungan hukum atas hilangnya hak atas tanah tersebut. ${ }^{8}$ Perlindungan untuk masyarakat perlu dipikirkan oleh pemerintah melalui aturan yang sudah ada saat ini. Melihat fakta dan data tersebut menunjukan bahwa lahan yang hilang akibat fenomena ala mini tidaklah sedikit. Rakyat yang kehilangan hartanya dalam hal ini tanah akan sangat dirugikan.

Sebagaimana teori perlindungan hukum yang dikemukan oleh Satjipto Rahardjo bahwa tujuan hukum dalam masyarakat adalah untuk mengintegrasikan dan mengkoordinasikan kepentingan-kepentingan masyarakat. ${ }^{9}$ Koordinasi kepentingan tersebut dapat dilakukan dengan cara perlindungan atas kepentingan tersebut. ${ }^{10}$ Sehingga diperlukan adanya perlindungan hukum terhadap hilangnya hak atas tanah milik warga masyarakat yang terkena abrasi di wilayah Kabupaten Brebes Jawa Tengah. Bentuk perlindungan yang ada harus bisa menyelesaikan masalah dan tidak menimbulkan potensi terjadi masalah baru yang akan datang dikemudian hari. Upaya-upaya progresif harus dilakukan oleh para pihak terkait seperti pemerintah daerah, DPRD serta pemerintah pusat, karena pihak yang secara langsung bersinggungan dengan permasalahan ini adalah pemerintah daerah.

Berdasarkan pada latar belakang tersebut maka permasalahan yang akan dibahas dalam penelitian ini yaitu seberapa besar dampak dari terjadinya abrasi di Kawasan Kabupaten Brebes terhadap masyarakat sekitar? Dan bagaimana pemerintah melindungi hak atas tanah yang dimiliki warganya karena terjadinya abrasi? Pada penulisan artikel ini menggunakan metode penelitian hukum normatif dan hukum empiris. Penelitian yang menggunakan metode normative yaitu penelitian yang berdasarkan pada sumber kepustakaan seperti buku, jurnal,

DOI: 10.14710/teknik.v32i2.1699.

6 Abdul Choliq, Awaludin Pimay, and Ahmad Anas, "PEMBERDAYAAN PESANTREN UNTUK PENANGGULANGAN ABRASI DI PANTAI DEMAK DAN JEPARA," Dimas: Jurnal Pemikiran Agama Untuk Pemberdayaan 15, no. 2 (2016): 1-27, 2, DOI: 10.21580/dms.2015.152.746.

${ }^{7}$ Dwi Susiati and Sri Setiadji, "STATUS HUKUM HAK MILIK ATAS TANAH YANG TERKENA ABRASI," Mimbar Keadilan 13, no. 1 (2020): 96-107, 97, DOI: 10.30996/mk.v13i1.3082.

${ }^{8}$ Wawancara dengan Lully Kasubag program BPBD Brebes, tanggal 20 Maret 2020 di Kantor BPBD Brebes.

${ }^{9}$ Satjipto Rahardjo, Ilmu Hukum (Bandung: Citra Aditya Bakti, 2000), 53

${ }^{10}$ Luthvi Febryka Nola, "UPAYA PELINDUNGAN HUKUM SECARA TERPADU BAGI TENAGA KERJA INDONESIA (TKI) (INTEGRATED LEGAL PROTECTION FOR MIGRANT WORKERS),” Negara Hukum: Membangun Hukum Untuk Keadilan Dan Kesejahteraan 7, no. 1 (2017): 35-52, 40, DOI: 10.22212/JNH.V7I1.949. 
dan berbagai sumber yang memiliki hubungan dengan penelitian ini. Kemudian penelitian hukum empiris adalah penelitian yang menggunakan data primer seperti wawancara yang disertai dengan data sekunder lainnya. ${ }^{11}$ Menjadi penting adanya tinjauan secara langsung mengenai permasalahan kali ini mengingat bahwa permasalahan ini tidak hanya bisa diselesaikan dengan teori dan konsep saja. Tetapi metode normatif tidak bisa dikesampingkan karena kondisi-kondisi empiris yang ada harus dihubungkan dan dikorelasikan dengan teori yang ada agar memiliki kekuatan secara ilmiah dan bisa dipertanggung jawabkan.

\section{B. Pembahasan}

\section{Penjelasan Abrasi}

Abrasi secara umum menurut KBBI pengikisan batuan dikarenakan oleh akibat angin, es, air atau bahan air lainya yang dapat bersifat merusak. ${ }^{12}$ Berdasarkan penjelasan tersebut dapat dilihat bahwa berbagai faktor yang menjadi penjebab terjadinya abrasi seperti air, angin, es. Jika dilihat fenomena yang terjadi di Indonesia. Abrasi yang terjadi hanya melibatkan faktor seperti angin, dan air, es tidak termasuk kedalam faktor penyebab terjadinya abrasi di Indonesia. Abrasi juga merupakan suatu peristiwa hukum yang diatur oleh Undang-undang No. 27 Tahun 2007 tentang Pengelolaan Wilayah Pesisir dan Pulau-Pulau Kecil yakni Pasal 31. Abrasi atau erosi pantai disebabkan oleh arus sepanjang pantai, gelombang laut ${ }^{13}$ serta sedimen yang menyusur pantai. ${ }^{14}$ Berdasarkan pengertian yang ditetapkan didalam undangundang memiliki perbedaan dengan definisi yang dijelaskan di dalam KBBI, Abrasi berdasarkan KBBI hanya menyebutkan secara umum bahwa penyebab terjadinya abrasi dikarenakan angina, es dan air, tetapi berdasarkan definisi yang telah ditetapkan di dalam undang-undang menjelaskan bahwa abrasi bisa terjadi dikarenakan arus sepanjang pantau dan gelombang laut serta adanya sedimen-sedimen yang berada sepanjang pantai.

Berkaitan dengan permasalahan pada tulisan ini, abrasi disebabkan karena pengangkutan sedimentasi secara terus-menerus yang menyebabkan adanya perpindahan garis pantai dalam jumlah besar yaitu sebesar 2.115 Hektar diantaranya kecamatan brebes sebanyak 506.81 hektar. ${ }^{15}$ Proses abrasi ini yang secara tidak langsung mengakibatkan banyaknya kerugian terhadap warga seperti kehilangan properti dan juga penyusutan pemukiman menjadi salah satu kendala yang dialami oleh warga pada saat bencana tersebut terjadi. Penyusutan lahan dan hilangnya properti warga atas bencana ini menjadikan tanah yang sudah terkikis dan tertutupi oleh air laut menjadi musnah dan hilang hak atas tanah milik warga setempat. Proses musnahnya tanah menurut pasal 40 UUPA yaitu jangka waktu yang telah berakhir, Berhenti sebelum waktu berakhir dikarenakan adanya suatu syarat tidak terpenuhi, atau sebelum jangka waktu berakhir pemegang hak tanah melepaskan haknya, dicabut karena kepentingan umum, diterlantarkan, tanahnya musnah. ${ }^{16}$ Pasal tersebut menjelaskan secara rinci mengenai

11 Felishella Earlene and Jesslyn Evelina Tandrajaya, "SENGKETA PENGUASAAN TANAH ANTARA WARGA KAPUK POGLAR RT 07 / RW 04 JAKARTA BARAT DENGAN POLDA METRO JAYA DITINJAU DARI PERSPEKTIF HAK ASASI MANUSIA,” Cepalo 3, no. 2 (2019): 55-62, 57, DOI: 10.25041/cepalo.v3no2.1844.

12 kbbi.web.id, s.v., “Abrasi”, diakses April 4, 2020, https://kbbi.web.id/abrasi

13 Hadi R Pranoto et al., "STUDI SEDIMENTASI PADA BANGUNAN GROIN DI PERAIRAN TIMBULSLOKO, KABUPATEN DEMAK,” Journal of Oceanography 5, no. 1 (2016): 86-95, 87.

${ }^{14}$ B. A. Hakim, Hidajat Suharyanto, "PERTANGGUNGJAWABAN PEMERINTAH REPUBLIK INDONESIA TERHADAP HILANGNYA HAK ATAS TANAH MILIK WARGA MASYARAKAT YANG TERKENA ABRASI DI WILAYAH KABUPATEN BREBES JAWA TENGAH". Proceedings of Efektifitas Penanggulangan Abrasi Menggunakan Bangunan Pantai di Pesisir Kota Semarang, Seminar Pengelolaan Sumber Daya Alam dan Lingkungan. Semarang: 11 September 2012, 11.

${ }^{15}$ Wawancara dengan Lully Kasubag program BPBD Brebes, tanggal 20 Maret 2020 di Kantor BPBD Brebes

16 I Gede Prapta Jaya, I Made Arya Utama, I Ketut Westra, "KEKUATAN HUKUM SERTIFIKAT HAK TANGGUNGAN DALAM HAL MUSNAHNYA OBYEK HAK TANGGUNGAN KARENA BENCANA 
penjelasan dari bagaimana proses musnahnya tanah pada UUPA, adapun penjelasannya seperti proses musnahnya tanah bisa dikarnakan waktu yang telah ditentukan telah berakhir, selanjutnya yang kedua adanya tindakan berhenti walaupun waktu belum berakhir atau ada suatu syarat tidak terpenuhi, serta hilangnya/musnahnya tanag dkarenakan pemegang ha katas tanah sudah melepaskan haknya secara menyeluruh, selanjutnya bisa dikarenakan dicabut dengan pertimbangan menganggu kepentingan umum, atau tanah tersebut telah ditelantarkan dan dibiarkan secara terus menerus serta yang terakhir karena tanah tersebut musnah atau hilang.

Dengan adanya status musnahnya tanah dan hak atas tanah milik warga tersebut maka status oleh tanah yang sudah tertutupi oleh laut dan terkena abrasi tersebut kembali menjadi milik pemerintah. Hapusnya hak atas tanah karena tanahnya musnah, Negara tidak dapat memberikan perlindungan hukum terhadap tanah yang musnah. Tanah tersebut menjadi musnah karena abrasi menyebabkan tanah musnah yang mana sudah di tentukan dalam Pasal 27 UUPA tentang hapusnya hak atas tanah, tanah yang musnah berarti tanahnya hapus. ${ }^{17}$ Pengaturan ini jelas bahwa tidak ada perlindungan mengenai tanah yang telah hilang akibat fenomena alam yang terjadi. Berdasarkan penjelasan tersebut memperlihatkan bahwa negara tidak mempunyai kewajiban untuk memberikan perlindungan kepada masyarakat yang kehilangan tanahnya dikarenakan abrasi yang terjadi dipinggir pantai. Status akan tanah yang terkena abrasi merupakan hak dari pemerintah bukan lagi menjadi milik pemilik tanah terdahulu.

Walaupun tanah tersebut telah menjadi milik pemerintah dan tidak dapat dikembalikan hak atas tanahnya kepada warga setempat tetapi pemerintah sendiri tidak dapat sepenuhnya dianggap bersalah dalam kasus tersebut dikarenakan telah diadakan sebelumnya tindakan preventif oleh pemerintah baik sebelum peristiwa tersebut terjadi maupun tindakan preventif untuk mencegah terjadinya kerusakan sewaktu-waktu terjadi bencana kembali kedepanya. Pasal 5 dari Undang Undang No. 24 Tahun 2007 mengenai penanganan bencana mengatakan bahwa pemerintah dan pemerintah daerah wajib menjadi penanggung jawab dalam rangka penyelenggaraan penangulangan bencana sehingga dengan adanya tindakan preventif oleh pemerintah ia tidak bisa dianggap melanggar hukum dan tidak bertanggung jawab. Sudah sangat jelas bahwa pemerintah tidak memiliki kewajiban untuk bertanggung jawab apabila sudah terjadi hilangnya tanah karena fenomena alam. Hal yang diatur didalam undang-undang hanya memberikan perlindungan sebatas upaya-upaya preventif. Upaya preventif ini pula tidak memiliki jaminan pasti dikemudian hari jika upaya yang telah dilakukan mengalami kegagalan dalam perjalanannya. Alam dengan segala fenomenanya seringkali tidak bisa diprediksi keadaan dan kondisinya. Terkadang alam memberikan hal yang positif dan baik kepada masyarakat sekitar, tetapi terkadang alam memberikan fenomena alam yang berdampak negatif dan memberikan efek yang merusak untuk wilayah sekitar yang telah ditempati oleh masyarakat.

Pemerintah telah berusaha untuk melakukan penanaman kembali hutan mangrove, meniadakan penggalian pasir pantai, membuat media atau saraba pemecah ombak oleh beton, dan pelestarian terumbu karang. ${ }^{18}$ Proses pencegahan sendiri dapat berupa berbagai macam yaitu seperti rehibilitasi hutan bakau yang sudah menjadi rusak akibat abrasi. Sengketa akan perebutan hak tanah akan tanah yang telah musnah tersebut oleh sebab itu tidak mungkin akan terjadi karena telah dijelaskan secara rinci status kepemilikan akan tanah tersebut oleh undangundang. Upaya-upaya preventif sudah dilakukan oleh pemerintah untuk melakukan pencegahan terjadinya abrasi di daerah pesisir pantai. Pemerintah telah melakukan

ALAM," Acta Comitas: Jurnal Hukum Kenotariatan 2, no. 2 (2017): 277-285, 282, DOI: 10.24843/AC.2017.V02.I02.P12.

17 Dwi Susiati, Op.Cit., 1.

${ }^{18}$ Wawancara dengan Lully Kasubag program BPBD Brebes, tanggal 20 Maret 2020 di Kantor BPBD Brebes. 
kewajibannya yang telah ditentukan oleh undang-undang. Fungsi dari adanya hutan mangrove adalah sebagai sarana pemecah ombak yang datang ke daerah pantai. Hutan mangrove dinilai efektif untuk menanggulangi permasalahan mengenai abrasi. Larangan mengenai penggalian pasir pantai sudah dilakukan, hal ini berguna untuk mencegah adanya air laut yang semakin ganas menerjang bibir pantai. Tidak hanya upaya yang berkaitan dengan alam, upaya-upaya buatan juga dilakukan oleh pemerintah. Beton-beton pemecah ombak dibuat untuk memberikan efek peredam ombak ketika adanya air laut yang berusaha menimbulkan adanya fenomena abrasi.

Upaya lainnya yang terus dilakukan merupakan adanya pelestarian terumbu karang, terumbu karang berfungsi untuk mencegah abrasi secara alami, tidak hanya mencegah abrasi tetapi upaya ini juga merupakan sarana untuk melestarikan terumbu karang yang ada. Sudah dijelaskan sebelumnya bahwa ruang untuk melakukan perebutan hak antara pemerintah dan pemilik tanah sudah tertutup. Undang-undang tidak memberikan legal standing untuk para pemegang hak tanah yang terkena abrasi untuk bersengketa dengan pemerintah. Undangundnag hanya memberikan ruang untuk pemerintah melakukan upaya-upaya pencegahan terhadap dampak yang ditimbulkan oleh fenomena alam seperti abrasi.

\section{Konsep Hak atas Tanah dan Pengaturanya}

Definisi dari hak atas tanah adalah hak yang diterima oleh perorangan dan juga badan hukum selaku penguasa atas tanah yang memberi kewenangan kepada pemilik hak atas tanah yang bersangkutan. ${ }^{19}$ Hak atas tanah melekat kepada pemilik hak selama tidak ada sesuatu yang bisa menimbulkan pemilik hak kehilangan haknya. Hak atas tanah merupakan hal yang kuat atas suatu kepemilikan benda yang ada di wilayah hukum Negara Kesatuan Republik Indonesia. Hak atas tanah sesuai yang telah diatur dalam pasal-pasal UUPA mengenai macam-macam hak atas tanah adalah pasal 4 ayat 1 dan 16 ayat 1 dan 53 pasal 4 ayat 1 dan 2, menjelaskan bahwa hak menguasai dari negara sebagai dimaksud dalam pasal 2 adalah hak penguasaan atas permukaan bumi yang dapat diberikan kepada orang-orang maupun bersamasama dengan orang-orang lain serta badan hukum lain. ${ }^{20}$ Hak-hak atas tanah yang dimaksud dalam pasal 2 ini menjelaskan bahwa wewenang atas tanah tersebut diatur dalam batas-batas peraturan perundang-undangan yang lebih tinggi, dimana hal tersebut dapat berupa TAP MPR atau mungkin penetapan presiden yang berhirarki lebih tinggi pada masa pembentukan UUPA.

Hak-hak atas tanah yang dimaksudkan oleh pasal 4 di atas diatur kembali pengklasifikasinya dalam pasal 16 ayat 1 dimana hak tanah dibagi menjadi: hak milik, hak guna-usaha, hak guna bangunan, hak mempunyai fungsi sosial. Berbagai hak tersebut melekat dengan berbagai fungsi yang melekat terhadap hak-hak tersebut. Hak milik biasanya terdapat dan digunakan kepada benda-benda, tanah dan sesuatu yang biasa diberikan dan dilekatkan hak milik, lain halnya dengan hak guna usaha atau dikenal sebagai HGU. HGU memiliki masa waktu yang ditentukan oleh undang-undang. Selama masa waktu yang ditentukan, pemegang HGU dapat menggunakan HGU untuk keperluan usaha yang ia miliki. Selain kedua hak tersebut terdapat hak guna bangunan, hak ini lebih spesifik ketimbang kedua hak tersebut. Hak guna bangunan hanya berfokus pada hak penggunaan bangunan yang telah ditentukan. Terlepas dari hak-hak yang sudah tercantum tersebut. Semua hak memiliki fungsi sosial, fungsi sosial memiliki arti bahwa hak milik, hak guna usaha, hak guna bangunan harus memiliki kebermanfaatan kepada masyarakat secara menyeluruh karena UUPA sangat

19 Imam Kusdarmanto, "STATUS PENGUASAAN TANAH TIMBUL DI KECAMATAN LOSARI KABUPATEN BREBES”, Tesis Fakultas Hukum Universitas Diponegoro, (2004), 29.

${ }^{20}$ Urip Santoso, Jalan Darmawangsa Dalam Selatan, and Jawa Timur, "EKSISTENSI HAK PENGELOLAAN DALAM HUKUM TANAH NASIONAL," Mimbar Hukum 24, no. 2 (2012): 276-288, 277, DOI: 10.22146/jmh.16130. 
mencerminkan aturan yang memang sesuai dengan nilai-nilai yang tercantum didalam UUD 1945 dan Pancasila. Adanya ketentuan pasal 15 UUPA mengenai kewajiban memelihara tanah dan larangan merusaknya. Khusus untuk tanah pertanian adanya ketentuan pasal 10 UUPA yang memuat asas bahwa tanah pertanian wajib dikerjakan sendiri oleh pemiliknya secara aktif. $^{21}$

Hak atas tanah yang diberikan oleh pemerintah juga memiliki batasan-batasan yang dibagi menjadi dua bagian yaitu batasan yang bersifat umum dan batasan terhadap hak itu sendiri. Pembatasan yang bersifat umum misalnya adalah, bahwa penggunaan wewenang tersebut tidak boleh menimbulkan kerugian bagi pihak lain atau menggangu pihak lain. Batasan ini ditentukan agar memang hak milik yang dimiliki seseorang dapat menghargai hak orang lain karena jika tidak ditentukan demikian, akan ditakutkan seseorang yang memiliki hak milik akan melakukan kesewenang-wenangan dalam menggunakan hak miliknya tersebut. Sedangkan untuk pembatasan atas tanah itu sendiri terletak pada klasifikasi dan jenis daripada tanah itu sendiri pada ciri-ciri dan sifat daripada tanah itu sendiri. Pembatasan tanah yang kedua ini menitik beratkan kepada ciri dan karakteristik sifat dari tanah tersebut.

Pembagian dari hak atas tanah itu dibagi menjadi beberapa jenis menurut pasal 16 UUPA yaitu: Hak atas tanah yang bersifat tetap, dan hak atas tanah yang bersifat sementara. Hak atas tanah yang bersifat tetap pakai, hak sewa, hak membuka tanah, hak memungut hasil hutan, dan hak-hak lainya. Kemudian diatur dalam pasal 53 UUPA, yaitu hak gadai, hak menumpang, hak sewa tanah, dan hak ulayat selaku diatur dalam UUPA pasal 3 . $^{22}$ Hak atas tanah selain mengandung kewenangan juga mengatur mengenai kewajiban yaitu: ${ }^{23}$

1) Adanya ketentuan dalam pasal 6 UUPA mengenai semua tanah meliputi:

a) Hak Milik

Merupakan hak turun temurun terkuat, dan terpenuh yang dapat dimiliki oleh seseorang atau badan hukum atas tanah dengan mengingat fungsi sosial. Bedasarkan penjelasan pasal 20 UUPA menjelaskan bahwa sifat dari hak milik tersebut yang membedakanya dengan hak - hak lainya. ${ }^{24}$ Terkuat dan terpenuh yang dimaksudkan adalah merupakan hak atas tanah yang mempunyai pengaruh paling kuat ketimbang hak-hak atas tanah lainya tetapi tidak melampaui hak kepemilikan eigendom sebagaimana diatur dalam pasal 571 KUHPerdata yang bersifat tetap, tidak dapat diganggu gugat,dan mutlak karena kewenanganya masih diatur dalam yurisdiksi peraturan perundang-undangan. Hak milik menjadi suatu hak yang bisa melindungi kepemilikan suatu benda. Kedudukan hukum dari hak ini sangat jelas terlihat memiliki kekuatan mengikat yang begitu kuat daripada hak-hak lain yang ada di dalam UUPA.

b) Hak guna usaha

Hak untuk mengusahakan tanah dalam jangka waktu 25 tahun bagi usaha perikanan, pertanian, atau perkebunan. batas waktu tersebut dapat diperpanjang 25 tahun atas permintaan pemegang hak atas pertimbangan keadaan perusahaanya. Hak guna usaha pada intinya merupakan hak yang dimiliki oleh negara terhadap sesuatu benda. Sebagai contoh hak guna usaha tanah yang digunakan oleh perusahaan-perusahaan gula. Tanah yang digunakan merupakan tanah milik negara dan harus dikembalikan kepada negara ketika masa jangka waktu yang telah ditetapkan oleh undang-undang telah berakhir.

\footnotetext{
${ }^{21}$ Nurhasan Ismail, "ARAH POLITIK HUKUM PERTANAHAN DAN PERLINDUNGAN KEPEMILIKAN TANAH MASYARAKAT," Jurnal Rechts Vinding: Media Pembinaan Hukum Nasional 1, no. 1 (2012): 33, DOI: $10.33331 /$ rechtsvinding.v1i1.105.

${ }^{22}$ Afra Fadhillah Dharma Pasambuna, "IMPLEMENTASI HAK PENGELOLAAN DAN PEMBERIAN HAK ATAS TANAH NEGARA”, Lex et Societatis 5, no. 1 (2017): 35-43, 37

23 Achmad Chulaemi, Hukum agraria, perkembangan, Hak atas tanah dan pemindahanya, (Semarang: $\mathrm{FH}$ Universitas Diponegoro, 1993), 89.

${ }^{24}$ Boedi Harsono, Hukum Agraria Indonesia: Sejarah Pembentukan Undang-undang Pokok Agraria, Isi dan Pelaksanaannya, (Jakarta, 1995), 227.
} 
Tentunya hak guna usaha harus memiliki fungsi sosial terhadap masyarakat sekitar. Semua ini diatur dengan tujuan agar negara Indonesia bisa mewujudkan cita bangsa yang tercantum di dalam Pancasila, sila kelima yaitu keadilan sosial bagi seluruh rakyat Indonesia.

c) Hak Guna Bangunan

Hak untuk mendirikan dan menggunakan bangunan atas tanah yang bukan miliknya sendiri dalam jangka waktu 30 tahun dan dapat diperpanjang kembali selama 20 tahun apabila ada permintaan dari pemegang haknya mengingat keadaan pembangunan dan keadaan keperluanya. Hak Guna Bangunan memiliki kesamaan dengan hak guna usaha. Kepemilikan kebendaan tersebut dimiliki oleh negara sebagai pemegang hak terkuat. Hak guna bangunan diberikan biasanya kepada perusahaan-perusahaan yang ingin menggunakannya sebagai usaha. Penyesuaian kebutuhan terhadap hak guna usaha ini akan dipertimbangkan oleh negara dalam segi pemberiannya. Jika memang pada keadaan-keadaan yang tidak perlu dan tidak dimungkinkan maka hak guna bangunan ini bisa tidak diperpanjang guna memenuhi kebutuhan utama yaitu kebutuhan nasional.

d) Hak Pakai

Hak untuk menggunakan dan atau memungut hasil dari tanah yang dikuasai langsung oleh negara atau tanah milik orang lain, yang memberi kewenangan dan kewajiban yang ditentukan dalam keputusan pemberianya oleh pejabat yang berwenang. Hak pakai tidak memiliki ambang batas waktu yang ditentukan didalam undang-undang. Hak pakai bisa sewaktu-waktu tidak diperpanjang kembali karena yang menguasai penuh dari hak ini adalah negara atau orang lain yang memiliki hak yang sah menurut hukum.

e) Hak Sewa

Hak yang memberi kewenangan untuk mempergunakan hak milik orang lain dengan membayar kepada pemiliknya sejumlah hak sewa. Hak Atas Tanah yang Bersifat Sementara. Maksud dari bersifat sementara adalah hak ini memiliki jangka waktu yang ditetapkan olek kedua belah pihak. Jika kesepakatan tersebut telah berakhir maka hak sewa akan hilang sesuai dengan perjanjian antara kedua belah pihak. Hak dan kewajiban melekat pada setiap pihak. Hak seorang penyewa mendapatkan manfaat dari apa yang telah disewa serta pemilik hak berkewajiban untuk memberikan hak yang melekat pada penyewa.

Hak ini bersifat sementara karena dalam sewaktu-waktu dapat dihapus hak ini diatur dalam pasal 53 UUPA hak ini diatur dalam pasalnya sendiri dikarenakan bertentangan dengan pasal 10 UUPA yaitu kepengurusan dari tanah harus dilakukan sendiri atau hak tersebut akan dihapus. Hak yang menjadi hak atas tanah bagi permasalahan tersebut adalah hak milik yang diberikan bagi masyarakat sepanjang pesisir pantai brebes terhadap segala rumah dan bangunan yang terendam abrasi adalah Hak guna bangunan dikarenakan oleh banyaknya masyarakat brebes yang masih kurang menyadari akan pentingnya pendaftaran hak tanah dan tidak mengubahnya menjadi sertifikat hak milik. ${ }^{25}$ Hak yang dimiliki oleh para masyarakat belum memiliki legitimasi yang kuat karena kelalaian dari masyarakat itu sendiri. Belum dibuatnya sertifikat hak milik menjadi permasalahan yang harus diselesaikan selanjutnya karena akan bisa membuat masyarakat kehilangan hak milik atas tanah jika belum terdapat sertifikat yang memberikan landasan hak yang kuat Hak guna bangunan sebagai salah satu dari hak atas tanah yang dapat membebani hak tanggungan merupakan salah satu hak yang paling penting dalam kehidupan masyarakat sehari-hari dikarenakan sifatnya yang mengikat dan masih berada dalam ketentuan UUPA Pasal 34 untuk dapat mengidentifikasi secara tepat apa saja pembatasan dalam hak guna bangunan.

Tanah yang tadinya merupakan hak mereka terhitung musnah setelah terjadinya peristiwa

\footnotetext{
${ }^{25}$ Wawancara dengan Edy Sumarsono Kepala Seksi Bpn Brebes, tanggal 20 Maret 2020 di Kantor BPN Brebes.
} 
abrasi yang dapat terhitung sebagai peristiwa bencana alam sehingga tanah yang tadinya memiliki status sebagai kepunyaan mereka sekarang ini menjadi kembali hak negara sesuai dengan ketentuan UU No.5 Tahun 1960 Pasal 37 mengenai hapusnya hak guna bangunan karena tanahnya musnah, sedangkan yang dimaksudkan dengan musnahnya tanah adalah keadaan tanah dimana tanah tersebut tidak dapat dipergunakan lagi secara fisik dan tidak dapat pula dipergunakan lagi ataupun tanah tersebut tidak lagi dapat deketahui bentuk fisiknya dikarenakan oleh bencana alam. ${ }^{26}$

Musnahnya tanah tersebut sudah diatur dengan jelas bahwa tidak ada kewajiban pemerintah untuk bertanggung jawab atas hilangnya tanah karena fenomena abrasi yang terjadi dalam permasalahan masyarakat tersebut. Syarat-syarat dari pasal tersebut telah terpenuhi seperti tanah tersebut sudah tidak bisa lagi dipergunakan secara fisik dan yang kedua, tanah tersebut tidak terlihat lagi bentuknya karena sudah hilang dikarenakan proses abrasi yang terjadi. Selanjutnya adalah kondisi dimana tanah tersebut hilang dikarenakan bencana alam. Fenomena abrasi masuk kedalam keadaan bencana alam walaupun abrasi tidak memiliki efek yang berlebiha seperti bencana-bencana banjir, tsunami, dan angina topan. Keadaan dengan adanya suatu penghapusan tanah tersebut menyebabkan banyaknya kendala yang terjadi kepada masyarakat setempat terutama dengan adanya peralihan hak atas tanahnya yang musnah itu. Penghapusan terhadap kondisi tanah tersebut akan menyebabkan status tanah tersebut sekarang kondisinya sebagai tanah milik negara. ${ }^{27}$ Implikasi adanya perpindahan hak milik dari masyarakat kepada negara bukan merupakan kemauan pemerintah. Pemerintah tidak melakukan tindakan yang melawan hukum atau bertindak sewenang-wenang dalam hal ini. Kondisi yang tidak terduga dalam hal ini adalah terdapat fenomena abrasi yang mengakibatkan tanah masyarakat tersebut hilang dalam jumlah besar.

\section{Pertanggungjawaban yang Seharusnya Dilakukan Pemerintah Terhadap Hilangnya Hak Atas Tanah Karena Abrasi}

Menelaah dan meninjau lebih jauh mengenai perlindungan hukum, perlindungan hukum dibagi menjadi dua macam yaitu terdiri atas perlindungan hukum preventif dan perlindungan hukum represif. Pertama perlindungan hukum preventif digunakan untuk melakukan pencegahan terhadinya sengketa terhadap suatu permasalahan, kedua, adanya tujuan dari perlindungan hukum represif adalah perlindungan hukum yang memiliki tujuan untuk menyelesaikan adanya sengketa setelah suatu permasalahan tersebut timbul. ${ }^{28}$ Berkaitan dengan masalah dalam tulisan ini menurut penulis pemerintah hanya memiliki mekanisme perlindungan hukum yang bersifat preventif bukan represif. Pemerintah hanya berkewajiban untuk melakukan upaya penanggulangan agar fenomena abrasi tidak terjadi. Pemerintah bukan tidak ingin melakukan perlindungan secara represif tetapi UUPA tidak mengatur mekanisme penyelenggaraan perlindungan hukum secara represif. Alasan tidak adanya penanganan secara represif karena hilangnya ha katas tanah yang dialami oleh masyarakat bukan merupakan kelalaian dari manusia atau pihak pemerintah, melainkan hilangnya hak atas tanah dikarenakan sebuah fenomena alam yang tidak bisa dikendalikan oleh manusia.

Ketika suatu daerah terkena abrasi atau bencana alam lainnya, hilangnya hak masyarakat atas tanah tersebut sesuai dengan konsep hilangnya hak atas tanah sebagaimana diatur dalam Pasal 27 UUPA, Pasal 34 UUPA, Pasal 40 UUPA. Mengenai pertanggungjawaban negara, dalam hal ini Negara merupakan pihak yang tidak dapat dipersalahkan kecuali Negara

\footnotetext{
${ }^{26}$ Tesa Herlina, "TINJAUAN YURIDIS TENTANG KEDUDUKAN SERTIFIKAT HAK GUNA BANGUNAN YANG TIDAK MEMILIKI IZIN MENDIRIKAN BANGUNAN DI ATAS TANAH ULAYAT YANG DISAKRALKAN", Skripsi Ilmu Hukum Perdata, Fakultas Hukum Universitas Pasundan Bandung, (2019), 36.

${ }^{27}$ Sigit Sapto Nugroho, Muhammad Tohari, Mudji Rahardjo, Hukum Agraria Indonesia, (Solo: Perum Gumpang Baru, 2017), 82.

${ }^{28}$ I Gede Prapta, Op.Cit., 283.
} 
terbukti membiarkan atau tidak melakukan usaha mencegah terjadinya abrasi. Negara sudah berada dikoridor yang seharusnya yaitu koridor hukum sesuai dengan ketentuan UUPA. Ketika pemerintah sudah melakukan pencegahan untuk melakukan abrasi maka pemerintah tidak perlu melakukan pertanggungjawaban karena pemerintah telah melakukan upaya yang maksimal. Sebaliknya masyarakat baru dapat mengajukan pertanggungjawaban pemerintah melalui gugatan class action jika pemerintah terbukti membiarkan dan tidak melakukan apaapa dalam hal pencegahan terjadinya abrasi. Pemerintah sebagaimana tertulis dalam Pembukaan UUD 1945 alinea ke-4 berkewajiban untuk melindungi segala tumpah darah bangsa, maka perlindungan terhadap hak-hak milik rakyat merupakan tanggung jawab publik pemerintah.

Sebagai contoh, kejadian tsunami di Aceh. Pada saat itu banyak sekali tanah rakyat yang hilang. Dalam kasus ini, Pemerintah melakukan pertanggungjawaban dengan menerbitkan kembali sertifikat tanah, melakukan pengukuran ulang untuk tanah/rumah yang mengalami kerusakan, sedangkan untuk tanah yang hilang karena bencana alam tersebut, pemerintah melakukan pertanggungjawaban dengan membangun rumah di tempat yang lain untuk mengganti tanah yang hilang tersebut. ${ }^{29}$ Tetapi kondisi yang adasaat ini berbeda dengan kondisi saat bencana tsunami di Aceh pada tahun 2004.

\section{Pertanggungjawaban Atas Hilangnya Hak atas Tanah Karena Abrasi yang Sudah Dilakukan Oleh Pemerintah}

Berkaitan dengan perlindungan hukum pasti akan berhubungan erat dengan adanya fungsi hukum. Fungsi hukum memang sebagai perlindungan tetapi harus dituangkan kedalam sebuah produk yang berisi mengenai kondisi-kondisi rigid yang bisa dilaksanakan dan di implementasikan agar kehidupan manusia berjalan sesuai semestinya. ${ }^{30}$ Fungsi hukum yang berusaha pemerintah jalankan mengenai perlindungan hukum sudah tercantum di dalam UUPA. UUPA sebagai dasar hukum untuk melaksanakan perlindungan hukum bagi masyarakat harus konsisten dilaksanakan. Sedangkan formulasi kondisi-kondisi rigid yang ditentukan didalam UUPA hanya menyediakan perlindungan hukum secara preventif dan tidak terdapat mekanisme perlindungan hukum secara represif.

Maka dari itu bisa dilihat bahwa fungsi hukum sudah berjalan sesuai dengan ketentuan yang berlaku dan sudah memenuhi kondisi-kondisi yang ditentukan oleh UUPA. Walaupun pemerintah daerah ingin membentuk aturan yang memberikan adanya kedudukan perlindungan hukum yang bersifat represif itu juga tidak dapat dilaksanakan, karena berdasarkan hirarki perundang-undangan tidak ada suatu aturan yang ada di bawah undangundang memiliki muatan yang bertentangan dengan isi muatan yang ada diaturan yang lebih tinggi. Seluruh aturan dan keputusan yang dikeluarkan pemerintah daerah harus berdasarkan UUPA. Jika ingin melakukan perubahan terhadap ketentuan perlindungan yang hanya bersifat preventif dan ingin ditambahkan substansi perlindungan hukum yang bersifat represif maka perlu terlebih dahulu dilakukan perubahan atau revisi terhadap UUPA, setelah dilakukan revisi dan perubahan. Pemerintah daerah baru bisa membentuk aturan yang bisa mengatur lebih lanjut perlindungan hukum secara represif.

Berdasarkan perlindungan yang telah dicantumkan, bahwa pemerintah daerah hanya memiliki kewenangan untuk melakukan perlindungan hukum yang bersifat preventif dalam permasalahan kali ini. Dalam mencegah hilangnya tanah milik rakyat karena terjadinya abrasi, Pemerintah Daerah Kabupaten Brebes bekerjasama dengan BNPB (Badan Nasional Penanggulangan Bencana) Kabupaten Brebes telah melakukan berbagai pencegahan di

\footnotetext{
${ }^{29}$ Wawancara dengan Hanafi Tanawijaya, S.H., M.H, tanggal 2 Maret 2020 di Kampus Universitas.

${ }^{30}$ Dadi Arja Kusuma, Rodliyah, and Sahnan, "SERTIFIKAT HAK MILIK ATAS TANAH SEBAGAI ALAT BUKTI HAK YANG KUAT CERTIFICATE OF THE PROPERTY RIGHT AS AN EVIDENCE OF POWERFULL RIGHT,”Jurnal Ius 5, no. 24 (2017): 312-21, DOI: 10.29303/ius.v5i2.465.
} 
antaranya:

a Penanaman kembali hutan mangrove di pinggir pantai yang saat ini luasnya hampir menutupi Panjang garis pantai Kabupaten Brebes yang saat ini panjangnya sepanjang 68.307,33 meter. Tujuan dari penanaman hutan mangrove adalah sebagai tumbuhan pemecah ombak alami. Hutan ini merupakan alat dan sarana yang efektif untuk memecah ombak air laut yang besar. Hutang yang memiliki akar yang kuat ini bisa menjadi aspek unggul dari hutan mangrove ini.

b. Meniadakan penggalian pasir pantai di seluruh wilayah pantai Kabupaten Brebes.

Kegunaan dari tidak adanya penggalian pasir pantai bermanfaat untuk memberikan daerah pantai menjadi kokoh dan kuat untuk menerima terpaan ombak yang datang.

c. Membuat media pemecah gelombang yang terbuat dari beton untuk membagi dan mengurangi kekuatan ombak yang menerjang daratan pantai.

Beton merupakan salah satu sarana buatan yang sudah sering digunakan untuk mengurangi adanya efek yang ditimbulkan dari ombak laut yang kuat. Tidak hanya sarana alami yang digunakan oleh pemerintah Kabupaten Brebes dalam menangani permasalahan ini tetapi sarana buatan seperti pembuatan beton ini sudah dilakukan.

d. Melakukan pelestarian terumbu karang pada wilayah perairan di sekitar garis pantai Kabupaten Brebes.

Upaya selain menanam tumbuhan mangrove adalah melakukan pelestarian terumbu karang. Terumbu karang berfungsi efektif untuk meredam ombak laut dari dalam air. Kekuatan dari ombak laut bisa dikurangi karena terhambat lewat bagian dalam air yang terdapat terumbu karang. Berbagai upaya dilakukan baik dari luar maupun dari dalam untuk mengurangi dampak dari ombak air laut yang bisa menyebabkan abrasi ini timbul.

e. Melakukan pengaturan zonasi wilayah pinggir pantai melalui Peraturan Bupati Kabupaten Brebes no 13 tahun 2019 tentang Rencana Tata Ruang dan Wilayah Kabupaten Brebes tahun 2019-2039, di mana Perda tersebut berisi ketentuan-ketentuan pemanfaatan wilayah pantai Kabupaten Brebes untuk mengurangi dampak terjadinya abrasi. Aspek hukum yang tertuang didalam peraturan bupati tersebut menunjukan adanya keseriusan dari pemerintah setempat untuk memang memberikan perlindungan hukum secara preventif agar tidak terjadi abrasi disekitar daerah pantai. Setelah lengkap instrument hukum yang telah dibuat, maka yang perlu ditingkatkan adalah mengenai konsistensi dari pelaksanaan peraturan bupati tersebut agar dilaksanakan secara efektif dan efisien.

Tindakan-tindakan pencegahan di atas dilakukan sebagi bukti tanggung jawab publik Pemerintah Daerah terhadap masyarakat yang bisa terganggu kehidupannya karena bencana alam abrasi tersebut. Menanggapi hilangnya hak atas tanah rakyat di beberapa wilayah Kabupaten Brebes, sesuai dengan ketentuan Pasal 27 UUPA, maka hak atas tanah tersebut otomatis hilang dan Pemerintah Daerah Kabupaten Brebes tidak melakukan penggantian apapun. ${ }^{31}$ Jika pemerintah melakukan tindakan yang tidak memiliki dasar aturan yang jelas, tentunya akan berbahaya bagi pemerintah daerah khususnya untuk mempertanggung jawabkan apa yang telah mereka lakukan. Salah satu jalan keluarnya adalah melakukan perubahan terhadap peraturan yang lebih tinggi yaitu pengaturan yang telah tercantum didalam UUPA, mengingat UUPA merupakan landasan hukum dalam menyelesaikan permasalahan tanah terkhusus berkaitan dengan mekanisme perlindungan hukum atas tanah yang musnah.

\section{Kesimpulan}

Proses Abrasi yang terjadi di Kabupaten Brebes pada Februari 2020 telah mengakibatkan hilangnya tanah di pesisir pantai sebesar kurang lebih $2.115 \mathrm{Ha}$ dengan rincian: 506,81 Ha di

\footnotetext{
${ }^{31}$ Wawancara dengan Lully Kasubag program BPBD Brebes, tanggal 20 Maret 2020 di Kantor BPBD Brebes
} 
Kabupaten Brebes, 626,15 Ha di Kecamatan Wanasari, 1,98 Ha di Kecamatan Bulakamba, 46,12 Ha di Kecamatan Tanjung, dan 934,33 Ha di Kecamatan Losari. Dari sekian banyak lahan yang hilang termakan oleh ombak, terdapat tanah-tanah yang dimiliki oleh warga, yang sebagian dimanfaatkan sebagai tambak. Terkait musnahnya tanah-tanah masyarakat tersebut, Pemerintah sesuai dengan ketentuan Pasal 27 UUPA tidak melakukan penggantian ataupun relokasi karena hak rakyat atas tanah-tanah tersebut musnah dengan sendirinya. Di sisi lain, Pemerintah Daerah telah melakukan berbagai upaya pencegahan untuk mencegah buruknya dampak yang ditimbulkan dari proses abrasi tersebut. Upaya-upaya pencegahan tersebut dapat dilihat sebagai bentuk tanggung jawab publik Pemerintah dalam menjaga kondisi alam sekaligus hak-hak masyarakat terhadap tanah yang dimiliki rakyat. Apabila masyarakat merasa tindakan pencegahan tersebut kurang tepat dalam mencegah bencana abrasi, masyarakat dapat mengajukan gugatan Class Action melalui Pengadilan Negeri setempat.

\section{A. Jurnal}

\section{DAFTAR PUSTAKA}

Choliq, Abdul., et.al. "PEMBERDAYAAN PESANTREN UNTUK PENANGGULANGAN ABRASI DI PANTAI DEMAK DAN JEPARA," Dimas: Jurnal Pemikiran Agama Untuk Pemberdayaan 15, no. 2, 2016: 1-27, DOI: 10.21580/dms.2015.152.746.

Dadi Arja Kusuma, Rodliyah, and Sahnan, "Sertifikat Hak Milik Atas Tanah Sebagai Alat Bukti Hak Yang Kuat Certificate of the Property Right As an Evidence of Powerfull Right," Jurnal IuS 5, no. 24 (2017): 312-21, DOI: 10.29303/ius.v5i2.465

Earlene, Felishella., Tandrajaya, Jesslyn Evelina. "SENGKETA PENGUASAAN TANAH ANTARA WARGA KAPUK POGLAR RT 07 / RW 04 JAKARTA BARAT DENGAN POLDA METRO JAYA DITINJAU DARI PERSPEKTIF HAK ASASI MANUSIA," Cepalo 3, no. 2, 2019: 55-62, DOI: 10.25041/cepalo.v3no2.1844.

Fajrin, Fadhilah Maharani., et al. "KARAKTERISTIK ABRASI DAN PENGARUHNYA TERHADAP MASYARAKAT DI PESISIR SEMARANG BARAT," Diponegoro Journal Of Maquares 5, no. 2, 2016: 43-50, DOI: 10.14710/marj.v5i2.11645.

Ismail, Nurhasan. "ARAH POLITIK HUKUM PERTANAHAN DAN PERLINDUNGAN KEPEMILIKAN TANAH MASYARAKAT," Jurnal Rechts Vinding: Media Pembinaan Hukum Nasional 1, no. 1 (2012): 33-51, DOI: 10.33331/rechtsvinding.v1i1.105.

Jaya, I Gede Prapta., Utama, I Made Arya., Westra, I Ketut. "KEKUATAN HUKUM SERTIFIKAT HAK TANGGUNGAN DALAM HAL MUSNAHNYA OBYEK HAK TANGGUNGAN KARENA BENCANA ALAM," Acta Comitas: Jurnal Hukum Kenotariatan 2, no. 2, 2017: 277-285, DOI: 10.24843/AC.2017.V02.I02.P12.

Kusdarmanto, Imam. "STATUS PENGUASAAN TANAH TIMBUL DI KECAMATAN LOSARI KABUPATEN BREBES". Tesis Fakultas Hukum Universitas Diponegoro, 2004.

Nola, Luthvi Febryka. "UPAYA PELINDUNGAN HUKUM SECARA TERPADU BAGI TENAGA KERJA INDONESIA (TKI) (INTEGRATED LEGAL PROTECTION FOR MIGRANT WORKERS)," Negara Hukum: Membangun Hukum Untuk Keadilan Dan Kesejahteraan 7, no. 1, 2017: 35-52, DOI: 10.22212/JNH.V7I1.949.

Pasambuna, Afra Fadhillah Dharma. "IMPLEMENTASI HAK PENGELOLAAN DAN PEMBERIAN HAK ATAS TANAH NEGARA”, Lex et Societatis 5, no. 1, 2017: 35 43.

Pranoto, Hadi R. et al. "STUDI SEDIMENTASI PADA BANGUNAN GROIN DI PERAIRAN TIMBULSLOKO, KABUPATEN DEMAK," Journal of Oceanography 5, no. 1, 2016: 86-95.

Raihansyah, Teuku., et.al. "STUDI PERUBAHAN GARIS PANTAI DI WILAYAH PESISIR 
PERAIRAN UJUNG BLANG KECAMATAN BANDA SAKTI LHOKSEUMAWE," Jurnal Ilmiah Mahasiswa Kelautan Perikanan Unsyiah 1, no. 1, 2016: 46-54.

Santoso, Urip. "EKSISTENSI HAK PENGELOLAAN DALAM HUKUM TANAH NASIONAL," Mimbar Hukum 24, no. 2, 20120: 276-288, DOI: 10.22146/jmh.16130.

Sudarsono, Bambang. "INVENTARISASI PERUBAHAN WILAYAH PANTAI DENGAN METODE PENGINDERAAN JAUH (STUDI KASUS KOTA SEMARANG)," Jurnal Teknik 32, no. 2, 2012: 162-169, DOI: 10.14710/teknik.v32i2.1699.

Susiati, Dwi., Setiadji, Sri. "STATUS HUKUM HAK MILIK ATAS TANAH YANG TERKENA ABRASI," Mimbar Keadilan 13, no. 1, 2020: 96-107, DOI: 10.30996/mk.v13i1.3082.

\section{B. Buku}

Chulaemi, A. Hukum Agrarian Perkembangan, Hak Atas Tanah dan Pemindahanya. Semarang: FH Universitas Diponegoro, 1993.

Harsono, B. Hukum Agraria Indonesia: Sejarah pembentukan Undang-undang Pokok Agraria,isi,dan pelaksanaanya. Jakarta: Djambatan, 1995.

Nugroho, S. S., Tohari, M., \& Rahardjo, M. HUKUM AGRARIA INDONESIA. Solo: Perum Gumpang Baru, 2017.

Raharjo, S. Ilmu hukum. Bandung: Citra Aditya Bakti, 2000.

\section{Peraturan Perundang-Undangan}

Undang-Undang Nomor 27 Tahun 2007 tentang Pengelolaan Wilayah Pesisir dan Pulau-Pulau Kecil (Lembaran Negara Republik Indonesia Tahun 2007 Nomor 84, Tambahan Lembaran Negara Republik Indonesia Nomor 4739)

Undang-Undang Nomor 5 Tahun 1960 tentang Peraturan Dasar Pokok-Pokok Agraria (Lembaran Negara Republik Indonesia Tahun 1960 Nomor 104, Tambahan Lembaran Negara Republik Indonesia Nomor 2043)

\section{Sumber Lainnya}

Hakim, B. A, Suharyanto., Hidajat, W. H. "Pertanggungjawaban Pemerintah Republik Indonesia Terhadap Hilangnya Hak Atas Tanah Milik Warga Masyarakat Yang Terkena Abrasi Di Wilayah Kabupaten Brebes Jawa Tengah". Proceedings of Efektifitas Penanggulangan Abrasi Menggunakan Bangunan Pantai di Pesisir Kota Semarang, Seminar Pengelolaan Sumber Daya Alam dan Lingkungan. Semarang, 11 September 2012.

Herlina, T. "Tinjauan Yuridis Tentang Kedudukan Sertifikat Hak Guna Bangunan Yang Tidak Memiliki Izin Mendirikan Bangunan Di Atas Tanah Ulayat Yang Disakralkan”. Skripsi, Universitas Pasundan Bandung, Fakultas Ilmu Hukum, 2019.

http://kbbi.web.id/abrasi, diakses pada 20 Maret 2020.

https://www.bnpb.go.id: https://www.bnpb.go.id/home/definisi, diakses pada 20 Maret 2020.

Lully Kasubag BPBD Brebes. (20 Maret 2020). Pengaruh abrasi terhadap kabupaten brebes.

Sumarsono, Edy Kepala seksi Humas BPN Brebes. (20 Maret 2020). Dampak Abrasi Terhadap Warga Sekitar Daerah Brebes.

Tanawijaya, H. (2 Maret 2020). Tinjauan perspektif hukum dalam kasus sengeta tanah abrasi Brebes. 
